\title{
Today's University Students and Their Need to Connect
}

\author{
Theresa J. Russo
}

State University of New York, College at Oneonta

Moira A. Fallon

State University of New York College at Brockport

Jie Zhang

State University of New York College at Brockport

\section{Veronica C. Acevedo}

Andrus Children's Center

\begin{abstract}
Higher education is rapidly changing and university instructors are presented with new types of students for whom technology is a significant influence. They perceive technology as a way of life and express a need to feel connected at all times. With increasingly diverse university classroom, technology integration is both a challenge and an opportunity. Supportive communication is important in the promotion of relationships and essential in a university classroom. A convenience sample of 390 students was surveyed to investigate the perceived influences of technology on relationships, including preferences, usage and time with technologies. Results indicated that technology makes communication easier, allows students to stay in touch with more people, and have relationships that would otherwise not be possible. Implications of this study suggest positive influences of technology on academic work, performance and maintenance of relationships. However, disadvantages with using technology such as increased stress, addictive feelings toward technologies, and increased misunderstandings in relationships and conflict also exist.
\end{abstract}

Key Words: Technology, communication, university students, relationships, higher education

Theresa Russo, Ph.D., is a Professor in Child and Family Studies at SUNY Oneonta. She is a Certified Family Life Educator through the National Council on Family Relations. Her research focuses on prevention programming and strengthening relationships for individuals and families Email: theresa.russo@oneonta.edu

Moira Fallon, Ph.D., is a Professor at SUNY Brockport in the Department of Education and Human Development. She has an extensive background in working with instructors and in improving the quality of instruction. She has published widely on issues of inclusion and advocacy for individuals with disabilities. and conducts research on instructional technology in higher education.

Jie Zhang, Ph.D., is an Associate Professor of special education at SUNY Brockport. Her research focuses on the cultural and linguistic factors in the services for children with diverse backgrounds/abilities and their families and the efficacy of different instructional methods on teaching and learning.

Veronica Acevedo is a Licensed Clinical Social Worker at Andrus Children's Center in Yonkers, New York. Her professional expertise is working with survivors of domestic violence and children who are emotionally disturbed, on the autism spectrum and learning disabled. She specializes in play therapy, grief counseling and Trauma Focused Cognitive Behavioral Therapy (TF-CBT). 


\section{Introduction}

Many believe that we are in the midst of one of the most dramatic technological revolutions in history (Harris, Wilson, \& Ferguson, 2010). As a result, education needs to evolve to meet the demands of a global society (Reinking \& Bridwell-Bowles, 1991). University instructors need to cultivate a variety of literacies within students to provide them with a competitive, economic edge. It is important for colleges and universities to understand the communication culture of technology use among university students, and it is critical to demonstrating the effects of communication upon organizational actions, control, coordination, survival, and also ideas, norms, values, behaviors, and goals (Gizir, 2007). Colleges and universities act as a cultural bridge to those new communication literacies, empowering individuals and groups traditionally excluded from education, thereby reconstructing the classroom to make it responsive to the challenges of an ever-changing society.

Many students entering higher education come from Generation X and Y (Wood, 2006). Today's university students have been referred to as both the Millennial and the Net Generation. Research (Howe \& Straus, 2000) on this generation suggests they are achievement oriented, more pressured to achieve academically, more confident in their abilities, accepting of diversity, and report feeling close and trusting of their parents. They are referred to as the Net Generation because they are technology savvy. They have grown up using computers and technology is at the core of their existence (Oblinger \& Oblinger, 2006). Their social networks have been established through use of technology and the internet. It is important for them to feel connected and use activities such as IM (Instant messages), text messages, on-line video games, music downloads, myspace and facebook as ways to reinforce social interaction (Oblinger \& Oblinger, 2006). Quan-Haase (2007) found the internet is integrated into university students' communication habits with family and friends both nearby and far away.

The technology savvy adolescents of today seem to have created a dependency on feeling connected (Crittenden, 2002) in both social and academic settings. They multitask, performing tasks at the same time (email, IM, video games, etc) and have created an expectation for speed and immediacy of response or information (Oblinger \& Oblinger, 2006). These adolescents prefer learning by doing and are more comfortable with image-rich environments rather than with text (Tapscott, 2002). The internet and technology has promoted and reinforced social interactions and created an environment of sharing and openness (Lenhart, Rainie \& Lewis, 2001). There is an emphasis on immediacy for access to friends, services and information among this generation (Prensky, 2001).

Life in a university setting has multiple configurations socially and cognitively (Gizir, 2007). Adolescents' academic communities and social networks are both physical and virtual interactions. On-line conversations may be as personal and meaningful to them as face-to-face (Oblinger \& Oblinger, 2006). However, Lenhart, Madden, and Hitlin (2005) found teens to report spending more time in the physical presence of their friends than interacting with them through technology. In addition, as students transition to universities the internet helps them maintain relationships with family and friends (Quan-Haase, 2007). Quan-Haase (2007) also found that students preferred interactive, synchronous forms of online communication, such as IM, over less immediate forms such as email.

From an ecological perspective, technology is part of the chronosystem due to its influence on the current generation. Technology has become part of the way we interact in our microsystems of family, friends and school by expanding on-line access and instant communication. The internet and technology is being used more and more to build social capital (Boase, Horrigan, Wellman \& Rainie, 2006). Adolescents today have reported that the 
internet plays a major role in their relationships with family and friends and enhances their social life (Lenhart, et al., 2001; Quan-Haase, 2008; 2007). According to Lenhart, et al., (2001), about half of teens in their study believe that the internet improves their relationships with friends, but $64 \%$ of them also reported it took away from the time they spent with their families. In their study, the phone was most often the way they contacted their friends $(71 \%)$, while $17 \%$ said instant messenger (IM) is most often used and $8 \%$ use emails. Quan-Haase $(2008,2007)$ found that students reported more social contact with friends than relatives, but IM was the most frequently used mode of communication with both friends and relatives. The internet can also allow students to limit their interactions. Lenhart et al. (2001) found that over half of teens in their study reported blocking messages or refusing to respond to someone with whom they don't want to communicate.

Technology has created a mixed reaction to relationships. Adolescents are able to feel more connected and have a wider array of social interactions through the use of the internet and cell phones. However, does this create an emotional dependence in these relationships? For example, university students reported communicating with their parents more than they thought they would, but this frequent contact may be keeping them from working things out on their own (Student Affairs Leader, 2006). Trice (2002) examined university students' emails to parents in context of parenting style. Attachment theorists believe that attachment style influences a person's ability to cope in stressful situations (Bowlby, 1973, 1980). Attachment theory would suggest that the purpose of the contact is more significant than the frequency of it. For example, university students with secure attachments would seek parental advice about their independent decisions rather than advice seeking as the purpose (Trice, 2002). University students who reported positive relationships with their parents were more likely to communicate with them by phone, while those who reported more anxious attachment and conflict with parents used social-networking sites (Gentzler, Oberhauser, Westerman, \& Nadorff, 2011). It seems that online communication, such as IM, is used to help students receive emotional support from family and friends (Quan-Haase, 2007). These online methods, however, were typically used to maintain relationships that had already been established.

Communication patterns between individuals help maintain and promote liking and satisfaction. Supportive communication is important in the promotion of relationships and can be essential in a university classroom. Although on-line communication can establish a sense of connectedness and immediacy, it is not without challenges. Researchers have found that online communication is sometimes an intrusion that creates tardiness and sleep issues among students (Massimini \& Peterson, 2009). Communicating on-line through email or instant message may reduce social cues, such as voice tone and facial expression that helps the receiver understand the context of the message (Friedman, 2005). There may be a greater risk of miscommunication or conflict in on-line discussions. Communication can be especially difficult for those university students for whom English is a Second Language (ESL).

Within the university setting, fields of study have varying organizational characteristics, such as ethics, modes of interaction, norms, and values. It was therefore important to develop an initial investigation of the influences of technology as perceived by university students in the north eastern part of the United States. This is particularly relevant as we see the current generation of college and university students being significant users of technology. Technology is introduced into our schools at the elementary and high school levels, and cell phone and internet use have become major vehicles of communication. It is important to find out how technology is perceived by students so that we can make recommendations regarding its use in classrooms and campuses. The purpose of this study was to explore the overall influence of technology on human ecology, including the frequency 
and maintenance of communication with friends and family, as well as the perception these technologies have on forming and maintaining relationships. Included in this survey were preference of technology usage, frequency of usage and time spent with technologies, such as cell phones, emails, instant messages and text messages. Participants' responses were not limited to any particular setting or place.

\section{Methods}

A convenience sample of 390 university students was collected over two semesters (Fall, 2008 and Spring, 2009) in introductory Family Studies courses in a northeast public university in the United States with a total student population of 5400 undergraduate students. It was believed that an on-line survey would be the most effective means of collecting data. The researchers did not find a complete survey instrument that was appropriate for use in this study. Therefore, an online survey was developed based on items used in several other research projects. An online survey was determined to be the best approach to reach as many students as possible who would complete the survey within a timely manner. An online survey approach was also used as the researchers determined it was most consistent with survey questions about technology use.

There were 44 males (11\%) and 345 females (89\%) in the sample. The sample was predominately traditional aged university students. They ranged in age from 18-29 years old. They were distributed across classes with $29 \%$ freshman, $30 \%$ sophomores, $28 \%$ juniors, and $14 \%$ seniors. They also varied in majors with child and family studies, food and nutrition, fashion, family and consumer science education, psychology, communication studies and a mixture of majors such as biology, music industry, or undeclared.

Survey items were developed for the instrument used in this study to understand the types, usage, and impact of communicative technologies have on college students' relationships. All survey items were generally related to the usage of current and available technology devices for college students. Survey items were selected from a variety of instruments measuring technology use. These instruments include survey tools from The Princeton Survey, Research Associates International for The Pew, Internet and American Life Project. In some cases, wording of the items was slightly adjusted for the age of participants and/or use of technology. Pew Research Center's Internet and American Life Project was leading the field in focusing on adolescents' use of technology and social media. With a generation of youth and adolescents integrating technology into their life, how would they use this technology on college campuses and to form and maintain relationships?

A reliability measure was obtained using internal consistency for the survey instrument after data collection. Total standardized Cronbach's alpha for the post-test survey was computed among all the survey items as .714 for total survey. Since the survey contained multiple concepts related to technology use and no items were scaled on the survey, alpha coefficients for reliability were not run (Tavakol \& Dennick, 2011). To increase content validity, expert appraisal of the survey instrument was sought. A three-member panel of experts in education and technology examined the face and content validity of the final version of the survey instrument. Their comments were incorporated into the discussion section of this paper. No additional pilot testing of the instrument was completed.

\section{Results}

Both descriptive and inferential analyses were used to investigate the survey results and to provide evidence for better understanding of the types, usage, and impact of communicative 
technologies have on college students' relationships. Both frequency and percentage of the descriptive analyses were reported regarding the usage, time, and access to technologies; and technology's impacts on relationships and communication. In addition, both one-way ANOVA and correlation coefficient were used to find out whether or not there were significant differences between different variables and technology.

\section{Descriptive Analyses}

Participants were asked about their perceived preference of usage, frequency of usage and time spent with technologies such as cell phones, emails, instant messages and text messages. Most of their time was spent with cell phone and instant messaging. Most (93\%) reported going online or using email several times a day ( 3 or more times). They were also asked about what technologies they use most to communicate with friends and family. For communication with friends, only $8 \%$ used land-line phones, while $95 \%$ report using cell phones to text their friends, $84 \%$ used cell phones to talk, $23 \%$ email, $76 \%$ IM. Communication with parents differed slightly in that $93 \%$ reported using cell phones to talk with parents, while only $41 \%$ used cell phones to text their parents, $21 \%$ used land-line phones to talk with parents, $42 \%$ emailed parents and $13 \%$ used IM.

\section{Relationship}

Students were asked if the internet improved their relationship with friends, $23 \%$ reported a lot, $45 \%$ some, $18 \%$ only a little and $8 \%$ not at all. When asked if the internet improved their relationship with family, $11 \%$ reported a lot, $24 \%$ reported some, while $25 \%$ reported only a little and 33\% reported not at all. They were also asked if the internet improves relationships with their boyfriend and girlfriend, $10 \%$ reported a lot, $27 \%$ some, $17 \%$ only a little, $31 \%$ not at all, while $15 \%$ were unsure. When asked if they used internet to make new friends, $37 \%$ reported they did and $62 \%$ reported they did not. They were also asked if more of their time was spent communicating face-to-face or through technology. Fifty-three percent reported through face-to-face and $47 \%$ through technology, but $80 \%$ reported preferring face-to-face communication, while $19 \%$ preferred using technology to communicate.

\section{Communication}

Students were asked if computers, cell phones and/or email changed the way they communicated and $72 \%$ reported yes, while $15 \%$ reported no, and $13 \%$ were unsure. When asked if overall communication devices made their life easier or more complicated, $66 \%$ reported they made life easier, while 3\% more difficult and 30\% reported they made it both complicated and easier. Ninety-one students reported that cell phones made them more available to other and $70 \%$ reported feeling stressed if their electronic devices were not available. They were asked to respond to a list of statements about the effect of technology on their relationships and whether they considered it to be true for them (see Table 1). The majority of the students reported technology to make communicating easier (84\%), that it allowed them to stay in touch with more people (92\%), that they had more relationships than would otherwise (36\%), that it allowed them to feel more connected (72\%). They also reported that it was easy to misunderstand what others mean (70\%), that it became addictive $(62 \%)$, that it caused too many distractions $(40 \%)$ and that when technology was not available they feel more stressed (51\%).

\section{Lack of Access}


One question was of particular interest to researchers in the study. Participants were asked, "If you were unable to use technology for a day; what impact do you think this would have on your life?" Of the 391 participants, less than ten percent (.0895) chose to respond to this prompt. A qualitative analysis was undertaken of participants' comments. In this analysis, participants attributed a higher number of negative influences to the lack of technology for a day than they did positive influences. The negative influences were distributed among feelings and relationships. Of interest was the little impact, positive or negative, on academic school work. Some participants anticipated problems, but were not specific as to difficulties.

Table 1: Qualitative Analysis of Comments

\begin{tabular}{|c|c|c|}
\hline & Positive Influences & Negative Influences \\
\hline Feelings & $\begin{array}{l}\text { Feel free }(22 \%) \\
\text { Relieved. }\end{array}$ & $\begin{array}{l}\text { Bored }(33 \%) \\
\text { Weird }(22 \%) \\
\text { Upset }(22 \%) \\
\text { Stress }(66 \%) \\
\text { I hate having to rely on technology for } \\
\text { everyday life. }\end{array}$ \\
\hline Relationships & $\begin{array}{l}\text { Fastest and easiest way to } \\
\text { communicate. } \\
\text { Technology keeps myself and a } \\
\text { long distant boyfriend connected. }\end{array}$ & $\begin{array}{l}\text { It would make things slightly more } \\
\text { difficult; but I would not say it causes } \\
\text { conflict. } \\
\text { Long-distance relationships are always } \\
\text { difficult. } \\
\text { Less connections with people ( } 22 \%) \text {. } \\
\text { A couple days to a week or longer would } \\
\text { negatively impact my relationships. } \\
\text { I need my cell phone while on campus in } \\
\text { case of an emergency with my children. } \\
\text { Its a little (sp) harder to communicate } \\
\text { with people not in town. }\end{array}$ \\
\hline Impact on School & More productive (22\%) & $\begin{array}{l}\text { It will cause problems with my school } \\
\text { work. }\end{array}$ \\
\hline Other & $\begin{array}{l}\text { Little or no impact }(22 \%) \\
\text { It would be nice for my cell phone } \\
\text { to stop ringing for a day. } \\
\text { Find something more productive to } \\
\text { do with my time. }\end{array}$ & $\begin{array}{l}\text { Liek im (sp) missing something. } \\
\text { Cause some problems. }(22 \%)\end{array}$ \\
\hline
\end{tabular}

\section{Gender}

Gender differences were investigated; however, these are cautiously interpreted since the majority of the sample was females. Both male and female students reported preferring faceto-face interactions to technology ( $89 \%$ compared with $11 \%$ and $79 \%$ and $20 \%$ respectively). Males reported more of their communications being face-to-face compared to using technology ( $68 \%$ vs $31 \%$ ), while female students reported $51 \%$ of their communications being face-to-face and 49\% through technology. Their responses regarding the effect of technology on their relationships were similar (see Table 2), with more females reporting feeling stressed when technology not available (52\% compared with 39\%) and reporting technology causes too many distractions ( $42 \%$ compared with $23 \%$ ). 
Table 2: Impact of Technology on Relationships

\begin{tabular}{|c|c|c|c|}
\hline & $\begin{array}{c}\text { All } \\
\text { Respondents }\end{array}$ & Males & Females \\
\hline Communicating is easier & $84 \%$ & $71 \%$ & $86 \%$ \\
\hline $\begin{array}{l}\text { There is more conflict in my } \\
\text { relationships on-line }\end{array}$ & $14 \%$ & $21 \%$ & $13 \%$ \\
\hline $\begin{array}{l}\text { Too easy to misunderstand what others } \\
\text { meant }\end{array}$ & $70 \%$ & $68 \%$ & $70 \%$ \\
\hline Stay in touch with more people & $92 \%$ & $80 \%$ & $94 \%$ \\
\hline $\begin{array}{l}\text { Have more relationships than would } \\
\text { have otherwise }\end{array}$ & $36 \%$ & $41 \%$ & $35 \%$ \\
\hline More misinformation about others & $30 \%$ & $34 \%$ & $30 \%$ \\
\hline $\begin{array}{l}\text { Feel more stressed when technology } \\
\text { not available }\end{array}$ & $51 \%$ & $39 \%$ & $52 \%$ \\
\hline Feel more isolated & $6 \%$ & $7 \%$ & $6 \%$ \\
\hline Feel more connected & $72 \%$ & $64 \%$ & $73 \%$ \\
\hline $\begin{array}{l}\text { Feel lonely even though connected on- } \\
\text { line }\end{array}$ & $8 \%$ & $9 \%$ & $8 \%$ \\
\hline Becomes addictive & $62 \%$ & $43 \%$ & $64 \%$ \\
\hline $\begin{array}{l}\text { Technology causes too many } \\
\text { distractions }\end{array}$ & $40 \%$ & $23 \%$ & $42 \%$ \\
\hline
\end{tabular}

\section{Inferential Analyses}

One-way ANOVA by whether or not the college students felt more productive caused by technology was analysed. There were significant differences between whether or not the participates felt more productive caused by technology regarding (1) using instant messaging to talk with friends $(\mathrm{F}=2.602, p=.036)$; (2) how many people they sent instant message to ( $\mathrm{F}$ $=4.610, p=.001)$; (3) watching TV shows or news programs via iPod $(\mathrm{F}=2.689, p=.031)$; and (4) using cell phone when sending and receiving e-mails $(\mathrm{F}=2.584, p=.037)$.

Significant differences were found regarding the statement of "I believe I am more productive because of my electronic devices" with instant messaging friends when not in person $\left(r=.111^{*}, p=.029\right)$; how often they used instant messaging to talk to people $(r=$ 
$\left..112^{*}, p=.028\right)$; how many people they sent instant message to on an average normal day $(r=$ $\left..185^{* *}, p=.000\right)$; watching TV shows or news programs on iPod $\left(r=.148^{* *}, p=.003\right)$; and using cell phone when sending and receiving emails $\left(r=.116^{*}, p=.023\right)$. Significant differences were found regarding the statement of "I like cell phone and other mobile devices allow me to be more available to others" ( $\left.r=.271^{* *}, p=.000\right)$; communicating was easier $(r$ $\left.=.179^{* *}, p=.000\right)$; too easy to misunderstand what others meant $\left(r=-.112^{*}, p=.028\right)$; staying in touch with more people $\left(r=.145^{* *}, p=.004\right)$; feeling more connected $\left(r=.211^{* *}\right.$, $p=.000)$; feeling lonely even though connected online $\left(r=-.200^{* *}, p=.000\right)$; and technology causes too many distractions ( $\left.r=-.121^{*}, p=.017\right)$.

One-way ANOVA by whether or not the college students felt technology helps communication was analysed. There were significant differences between whether or not the participants felt technology helps communication regarding (1) using landline phone $(\mathrm{F}=$ 9.021, $p=.003)$ or instant messaging $(\mathrm{F}=5.586, p=.019)$ to talk with friends when not in person; (2) using instant messaging to talk with parents when not in person $(\mathrm{F}=3.963, p=$ $.047)$; (3) the total time they spent to instant message people on an average normal day $(\mathrm{F}=$ $8.591, p=.004)$; (4) the way they preferred to communicate $(\mathrm{F}=14,528, p=.000)$; (5) whether or not the use of a computer, cell phone, and/or email changed the way they communicated $(\mathrm{F}=9.776, p=.002)$; $(6)$ how often they used instant messaging to talk to people $(\mathrm{F}=11.619, p=.001)$; (7) primarily using a blackberry, or PDA $(\mathrm{F}=3.935, p=.048)$ or cell phone $(\mathrm{F}=4.088, p=.044)$; when sending and receiving e-mails; and (8) whether or not they own TV with them at school $(\mathrm{F}=8.011, p=.005)$.

Significant differences were found regarding the statement of "communication devices make my life easier or more complicated" with using cell phone $\left(r=.125^{*}, p=.014\right)$ or email $\left(r=-.121^{*}, p=.017\right)$ to talk with friends when not in person. In addition, significant differences were found regarding the statement of "I like cell phone and other mobile devices allow me to be more available to others" $\left(r=.259^{* *}, p=.000\right)$; preferred way to communicate $\left(r=-.117^{*}, p=.022\right)$; communicating was easier $\left(r=.150^{* *}, p=.003\right)$; too easy to misunderstand what others meant ( $\left.r=-.186^{* *}, p=.000\right)$; more misinformation about others $\left(r=-.158^{* *}, p=.002\right)$; and technology causes too many distractions $\left(r=-.176^{*}, p=\right.$ $.000)$.

\section{Summary of the Results}

The results of this study indicated that technology, especially cell phones, e-mails, and internet, played an important role in the participants' daily life, such as communication and relationship development/maintenance. Interestingly, even though most participants reported preferring face-to-face communication, only half of them spent most time communicating face-to-face. Most participants claimed that technologies changed the way they communicated, made communication and life easier, made them be more available to other and more connected to others. However, most participants reported that they felt stressed without their electronic devices, technology made it easy to misunderstand what others mean, and caused too many distractions.

The more often the participants used IM to talk with friends, the more people they sent IM, the more often they watched TV via iPod, or the more often they used cell phone when sending and receiving e-mails, more productive they felt caused by technology. In addition, more productive the participants felt caused by technology, the stronger they felt technologies allowed them to be more available to others, made communication easier, stayed in touch with more people, felt more connected; yet too easy to misunderstand what others meant, felt lonely even though connected online, and caused too many distractions.

Brock Education, 23(2), Spring 2014, pp. 84-96 
The more often the participants used technology to talk with friends/parents, more time they spent using technology, or the stronger they believed that technologies changed the way they communicated, the stronger they felt technology helped communication. In addition, the stronger they felt technology helped communication, the stronger they felt technologies made their life easier, allowed them to be more available to others, made communication easier; yet too easy to misunderstand what others meant, and caused too many distractions.

\section{Discussion}

Higher education today is rapidly changing and university instructors are being presented with new types of students. Technology has become a significant influence in the lives of adolescents and young adults. It is a means of communication that has become a lifestyle for the Millennial and Net generations. This study was an attempt to provide university instructors with a better understanding of the role of technology in the lives of university students and their need to connect with families and friends. Therefore, undertaking a cultural analysis of technology use within a university setting requires careful analysis of understanding the role of technology in the lives of students on campus (Gizir, 2007). The purpose of this study was to explore the overall influence of technology on human ecology, including the frequency and maintenance of communication with friends and family, as well as the perception these technologies have on forming and maintaining those relationships.

\section{Relationships with Family and Friends}

Consistent with other research, university students in this study believe that technology devices help improve and maintain their relationships with both family and friends (Lenhart, et al., 2001; Quan-Haase, 2007; Gentzler, et al., 2011). Students reported talking more to their parents on cell phones, while more frequently texting friends with cell phones. This finding did differ with Quan-Haase (2007) who found students preferred IM over cell phone use. However, this is most likely due to cost of cell phone use in Canada versus the United States. The majority of students reported preferring face-to-face communication, but then they reported almost equal amounts of time were spent communicating face-to-face and through technology.

For today's students, the use of technology plays a major role in their relationships with family and friends, but is also time consuming (Lenhart, et al., 2001; Quan-Haase, 2007; Massimini \& Peterson, 2009), can create a sense of dependency on or addiction of feeling connected (Crittenden, 2002; Campbell, Cumming \& Hughes, 2006), and can increase perceived stress in students' lives. There are advantages and disadvantages to technology based communication.

This study was consist with others in that technology makes communication easier and allows students to stay in touch with more people and have relationships that otherwise may not have been possible. However, it is easy to misunderstand what others mean through this type of interaction and more potential miscommunication and conflict. Today's university students value their parents' opinion, report feeling close to their parents and seeking their approval, and don't mind their parents handling things for them (Howe \& Straus, 2000; Horne, 2006). As a result, this may create a dependency on their parents to solve their problems, have parents over-involved in their education, and create deficiencies in their interpersonal communication skills.

\section{Relationships with Faculty and Classroom Interactions}


Faculty are faced with classrooms of Millennial and Net generation students that are focused academically on achievement and grades. These students perceive technology as a way of life and express a need to feel connected at all times, they view learning as a game-playing trial and error process rather than a linear process, they are used to multitasking, and they have a zero tolerance for delays (Horne, 2006). In the classroom, they expect 24/7 service, have an expectation of self-service on-line, an expectation for fast service and desire an experiential, interactive, authentic learning with on-line connections and community (Horne, 2006). Students also believe that technology can cause distractions and become addictive. An indicator of this is the significant amount of time spent in a day using these technologies.

Students report issues related to on-line technologies and cell phone use result in class tardiness and loss of sleep (Massimini \& Peterson, 2009). As a result of many students feeling addicted to the use of technology, they may also experience stress when it is not available for them to use. Additionally, anxiety may increase when those around them are not responding within the immediacy they expect. This perceived stress related to interactive technologies, was found in this study and by Massimini and Peterson (2009). It may be that students use these technologies to seek out support from family and friends, but they also become an intrusion in everyday life and increase a student's perceived stress and anxiety.

As university instructors consider the use of technology in the classroom, it is important they consider the role culture plays. Teachers contribute enormously to a positive social climate (Kaya, Ozay, \& Sezek, 2008). The rich diversity of students may impact university instructors' assumptions that all students bring the same skill sets to university classrooms, particularly in terms of reading or language ability. The challenge is to understand all students' communication patterns and find effective teaching methods. Technology allows students to operate around the clock from any location, whereas university calendars and faculty and class schedules are fixed; technology emphasizes group and shared work products, whereas universities emphasized individual work products; and technology allows for multitasking, individualized and interactive learning with content and modes of learning that were concrete and active, whereas faculty emphasized sequential tasking. Understanding these differences is the first step in changing patterns of communication among faculty and university students.

\section{Study Limitations}

Limitations to this study include a sample of convenience, which was heavily dominated by female participants The majority of the participants were taking an introductory course in Family Studies, which may have influenced ideas or perceptions of relationship issues. This study was an exploratory beginning to looking at the influence of technology on relationships conducted in the northeastern part of the United States. Issues of culture and regionality may influence perceptions, particularly in communication. Further study needs to be done regarding the impact of technology on communication patterns, possibly qualitative data such as in-depth interviews or focus groups that will allow for a deeper discovery of student perceptions and communication patterns. Technology will continue to be a significant influence in the lives of individuals and families, and in university classrooms.

\section{Conclusion}

Institutions and faculty contribute enormously to a positive learning climate in the university classroom. We need to continue to use effective technologies within the university classroom 
in order to reach all students. We also need to work to educate university students on how to use these forms of communication as effective means of human and interpersonal interactions. Many universities utilize centers of teaching and learning to assist faculty members to be effective in online and hybrid courses. Such professional development by the institution for faculty members can help develop effective communication techniques among faculty members and their students.

Technology should be used with the needs of the learners in mind and with the goal of improving student learning as the focus There are advantages and disadvantages to communicating with technology, but with almost half of university students reporting that most of their interactions are not face-to-face we need to better understand the implications for interpersonal relationship development and student-faculty interactions. 


\section{References}

Boase, J., Horrigan, J. B., Wellman, B., \& Rainie, L. (2006). The strength of internet ties. . Washington, D.C.: Pew Internet and American Life Project.

Bowlby, J. (1973). Attachment and loss: Vol. II. Separation: Anxiety and anger. New York: Basic Books.

Bowlby, J. (1980). Attachment and loss (Vol. 3). New York: Basic Books.

Campbell, A. J., Cumming, S. R., \& Hughes, I. (2006). Internet use by the socially fearful: Addiction or therapy? CyberPsychology \& Behavior, 9(1), 69-81.

Crittenden, S. (2002). Silicon daydreams: digital pastimes of the wired generation. Virgina.edu, vol VI. http://www.itc.virginia.edu/fall02/daydreams/home.html.

Friedman, R. (2005). Email escalations: dispute exacerbating elements of electronic communication. http://mba.vanderbilt.edu/ray.friedman/pdf/emailescalation.pdf.

Geary, M., (2010). Technology connecting curriculum, instruction, and assessment. In M. Fallon \& S. Brown (Eds.) Teaching inclusively in higher education. Charlotte, NC: Information Age Publishing Co.

Gentzler, A. L., Oberhauser, A. M., Westerman, D., \& Nadorff, D. K. (2011). College students' use of electronic communication with parents: links to loneliness, attachment and relationship quality. Cyberpsychology, Behavior, and Social Networking, 14(1-2), 71-74.

Gizir, S. (Spring, 2007). A review on organizational culture and organizational communication in universities Educational Administration: Theory and Practice, 50, 247-268.

Harris, S., Wilson, J., \& Ferguson, J. (2010). Reaching students through a virtual community. In M. Fallon \& S. Brown (Eds.) Teaching inclusively in higher education. Charlotte, NC: Information Age Publishing Co.

Horne, P. (2006). Understanding the millennial generation. Office of Admissions and Scholarship, Michigan State University. Lansing: MI.

Howe, N. \& Stauss, W (2000). Millennials rising. New York: Vintage Books.

Kaya, E., Ozay, E., \& Sezek, F. (2008). Application of a questionnaire to describe teacher-students communication behaviour in a university in turkey.

International Journal of Environmental \& Science Education, 3(1), 26-29. 
Lenhart, A., Madden, M. \& Hitlin, P. (2005). Teens and technology: Youth are leading the transition to a fully wired and mobile nation. Washington, D.C.: Pew Internet and American Life Project.

Lenhart, A., Rainie, L. \& Lewis, O. (2001). Teenage life online: the rise of the instantmessage generation and the Internet's impact on friendships and family relationships. Washington, D.C.: Pew Internet and American Life Project.

Massimini, M. \& Peterson, M. (2009). Information and communication technology affects on U.S. college students. Cyberpsychology: Journal of Psychosocial Research on Cyberspace, 3(1), 1-10.

Oblinger, D. \& Oblinger, J. L. (2006). Is it age or IT: first steps toward understanding the net generation? California School Library Association Journal, 29(2), 8-16.

Prensky, M. (2001). Digital natives, digital immigrants. Part II: Do they really think differently? On the Horizon, 9(6), 15-24.

Quan-Haase, A. (2008). Instant messaging on campus: Use and integration in university students' everyday communication. The Information Society, 24(2), 105-115.

Quan-Haase, A. (2007). University students' local and distant social ties: Using and integrating modes of communication on campus. Information, Communication \& Society, 10(5), 671-693.

Reinking, D. \& Bridwell-Bowles, L. (1991). Computers in reading and writing. In R. Barr, M. L. Kamil, P. B. Mosenthal, \& P. D. Pearson (Eds.) Handbook of reading research (Vol. 2, pp. 310-340). New York: Longman.

Student Affairs Leader (2006). Study Examines the Impact of the 'Electronic Tether'. Student Affairs Leader, 34, 1-2.

Tavakol, M. \& Dennick, R. (2011). Making sense of Cronbach's alpha. International Journal of Medical Education, 2, 53-55.

Trice, A. D. (2002). First semester college students' email to parents: I frequency and content related to parenting style. College Student Journal, 36(3), 327-334.

Wood, G. (2006). Recognizing the generational divide: When x meets y at the tribal college. Tribal College Journal, 17(4), 24-25. 